\title{
IJRTBT FUTURE TRENDS IN EMPLOYEE REQUIREMENT IN HOTEL AND RESTAURANT SECTOR IN SRI LANKA
}

\author{
K.A.S. Kulasingha ${ }^{1}$, H. M. S. Priyanath ${ }^{2 *}$ \\ ${ }^{1}$ Sri Lanka Institute of Tourism and Hotel Management, Colombo, Sri Lanka \\ ${ }^{2}$ Department of Economics and Statistics, Sabaragamuwa University of Sri Lanka, Belihuloya, Sri Lanka \\ *Corresponding Author's E-Mail: priya@ssl.sab.ac.lk
}

\begin{abstract}
This paper aims to forecast future employee requirements in the hotel and restaurant sector in Sri Lanka and identify the correlation between different labour categories with tourist arrivals. The literature illustrates the fact that there is a significant shortage of forecasted data on labour in the hotel and restaurant sector, particularly in Sri Lanka. Therefore, this research fulfilled the empirical gap forecasting the future employee requirements in the hotel and restaurant sector in Sri Lanka. Secondary data were used and analyzed using quantitative techniques. Annual data were obtained from annual statistical reports from 2000 to 2018 published by Sri Lanka Tourism Development Authority in Sri Lanka. The linear regression model was used to forecast different employee categories in the hotel and restaurant sector and Karl Pearson's correlation was used to test the correlation between labour categories (independent variables) and tourist arrivals (dependent variable). Findings indicate that there is a positive and very strong relationship between tourist arrivals and different labour categories since the coefficient of correlation is more than 0.8 in all relationships. The study forecasts that 2.4. million foreign tourists will arrive in Sri Lanka in 2024 and 146105 employees in different categories in the hotel and restaurant sector in Sri Lanka is required. As compared to the required labour force with the existing employees, hotel and restaurant sector in Sri Lanka is required 24898 employees in 2024. Thus, the study provides better insight into future trends of employability requirements of the hotel and restaurant sector which leads to preventing the risk and uncertainties in future manpower planning in the industry.
\end{abstract}

\section{Keywords: Employees; Forecasting; Hotel and Restaurant; Sri Lanka}

\section{INTRODUCTION}

Sri Lanka is predominant in agriculture producing paddy, vegetables, grain, yam, and fruits for domestic consumption and cultivating commercial crops including tea, rubber, coconut, and spices. Agriculture contributed $7.8 \%$ to the Gross Domestic Product (GDP) in 2019 (Central Bank of Sri Lanka, 2019). The service sector emerged as the dominant sector which included trade, transport, tourism, communication, financial services, public administration, national defiance, and other services, contributed 61.7 per cent of the GDP in 2019 (Central Bank of Sri Lanka, 2019). However, over the past few years, the industrial sector has grown significantly. It has contributed 30.5 per cent to the GDP in 2019 (Central Bank of Sri Lanka, 2019). This information indicates that the contribution of the service sector in GDP is continually decreasing higher than the agriculture sector. This should be a good indicator for the policy decision-makers to take decisions to find out new avenues for the development of the service sector further. The agriculture sector reached the maximum capacity of utilizing all the arable lands in Sri Lanka. Therefore, employment generation in the agricultural sector is limited. Having understood the above situation, the Sri Lankan
Government made attempts to find new opportunities to develop the service sector in the next decade for the acceleration of its economic growth. Especially after post-war development 2009, tourism was identified as the largest and fastest-growing industry in Sri Lanka (Suresh \& Senethilnathan, 2014).

Tourism is an industry that generates multiple effects on the national economy. It contributes a lot of economic advantages to both developed and developing countries. It facilitates business development, employment growth, social development, cultural and environmental quality, and economic growth (Onetiu \& Predonu. 2013). Tourism development is seen by many developing countries and regions as an opportunity for economic and social development (Mihalic, 2016) and Tourism development and economic growth have a long-term positive association. This has been proven by Greece (Dritsakis, 2004), Italy (Massidda \& Mattana, 2013); and many other countries. On the other hand, tourism is basically labour intensive. Hence, its importance to Sri Lanka economy is high. As a country, Sri Lanka labour force is estimated as 8334316 persons (Sri Lanka Labour Force Survey, 2019) and out of it, Agriculture employs 25.23 per cent of the labour force, industry produces 29.09 per cent, and the service sector 
employs 45.6 per cent of the total workforce. The tourism sector contributed to 11 per cent of total employment. The tourism industry involves approximately 488,000 people and is anticipated to boost by 1.6 per cent each year until it reaches $1,037,000$ by 2028 . Unemployment has historically been a very sensitive issue in Sri Lanka (Dickens \& Lang, 1991). In 2017 , the unemployment rate for above 18 was at $4.4 \%$. Hence, tourism is not only important for economic development but also important to employment generation (ILO, 2020). As a labor-intensive industry, manpower is the most pressing long-term problem facing the tourism industry. As per the International Society of Hospitality Consultants (ISHC), the number one concern facing the global hospitality business is focusing on the labour force. Hence, government as well as other private sector decision-makers should take the necessary attention to solve problems in tourism labour in future. Tourism HR research has been measured in two ways: HR requirements (industry personnel demands) and employment impact studies. (Ritchie \& Goeldner, 1987). HR requirements research means research within the firm and often deals with people and planning areas. Employment impact studies are used to determine past, current, and possible further effects of travel and tourism on employment and earnings. These researches are used for planning for industry expansion, identify viable markets within available labour supply, provision of government grants. Statistical data are critical for making informed, evidence-based decisions, planning, implementing, and monitoring policies and programmes. As a result, the level of detail and trustworthiness of data, as well as its interpretation and use, have a direct impact on the efficacy of such policies and initiatives. For any country, statistics on the tourism labour market provide the following advantages:

1) It can be used to define and analyse the present employment situation in various industries in terms of the number of people employed, the number of jobs available, labour utilisation, and job demands.

2) It examines how tourism flows and expenditure affect employment levels and structure in various tourism industries.

3) Policymakers can use employment data to conduct analysis at various degrees of detail and check for consistency with financial data.

In the Sri Lankan context, there are very little research carried out to identify and understand the nature of the labour market in the tourism and hospitality sector (Umasuthan \& Park, 2018). In the direct labour force in the tourism sector, approximately $80 \%$ of tourism labour in Sri Lanka represents the hotel and restaurant sector (SLTDA, 2019). Though this sector provides a large portion of the job market of the tourism sector, greater attention is not given to the future development of this sector. One of the reasons for the above scenario may be no proper information available in this sector for decision-makers. According to Armstrong \& Taylor (2020), employment forecasting is the process of anticipating future employee numbers as well as the expected skills and abilities required. Forecasting attempts to minimize risks associated with industry and maximize the productivity of decisions making of the entire industry but fewer attempts were made in forecasting employment in the tourism industry in Sri Lanka. Among the very few or no attempt is taken to forecast future labour in the hotel and restaurant sector in Sri Lanka. Hence, it is a timely requirement of forecasting the employment of this valuable sector.

\section{LITERATURE REVIEW}

The labour force is defined as the sum of employed and unemployed people, according to ILO labour force projections for 2020. People in employment are defined as individuals of working age who were engaged in any activity to generate products or services for pay or profit during a short reference period. They comprise; a) Employed persons, 'at work' (at least one hour), and b) Employed persons 'not at work' due to temporary absence from a job or to working -time arrangements.

The labour force of a particular country is highly influenced by the factors such as technology changes, societal changes, internalization of products, etc. Most economic and institutional decisions are related to the current labour market in the country. Therefore, it is important to understand the future trends and behaviours of the labour market for the decision-makers so that they can take the most accurate decisions in future. Contributions of O'Connell \& MacGinnity (1996) demonstrate that these forecasts have provided accurate and relevant information on labour market developments. Even this information is important for individuals, firms and institutions which ensure employability is a key element of any strategic response. Even yet, this data is critical for individuals, businesses, and institutions who want to guarantee that employability is a core component of any strategy response. Individual wealth will increase as a result of well trained and educated workers, corporations will become more competitive, and society as a whole will benefit (Neugart \& Schömann, 2002). Forecasting labour market developments has a lengthy history throughout the world. The Mediterranean Regional Project, started by the OECD in the early 1960s, 
was one of the first "Manpower Planning Projects." The forecasting labour force in an industry or country provides several benefits. Forecast enables an organization to find a more strategic approach to identify and subsequently solve problems. It helps to reduce adjustment costs arising from imbalances in the labour and product markets (Neugart \& Schömann, 2002). It encourages investments in education and training, the deployment of labour market instruments and policy development in the field of personal and policy development (ADB \& ILO, 2017). Labour forecast provides both occupational guidance for new labour market entrants as well as address the need for occupational mobility for those already in a job or those seeking to re-enter the labour market. In general, employment data is an important social indicator for understanding a country's specific economy. These data reveal the number of jobs, people employed, their qualifications etc. It is critical for policymakers to have access to accurate statistics to conduct job-creation policies and initiatives in the country.

Like the industry, tourism plays a pivotal role in the labour market since it generates a substantial share of total jobs. It provides employment opportunities for different segments of people in society and sometimes these segments are neglected by other industries. For example - individuals who seek jobs the first time, low skilled workers and workers with little qualification. The tourism industry's impact to the creation of jobs is difficult to quantify. Since it is a very complex field in terms of employment generation, the actual employee figure of the tourism sector can be hidden. The causes behind the above scenario can be identified as follows. Season ability (part-time), an excessive hour of work, low paid and family labour, informal or sometimes illegal labour. There are two conceptual measures of tourism labour. They are referred to as tourism jobs and tourism industry employment. Employment in tourism is tied to the goods and services purchased by visitors and created by tourism or other businesses. It counts the number of employments in the tourist and non-tourism industries that are directly related to tourism demand and are held by employees, self-employed people, and family workers. All jobs (in all occupations) in the tourism industry are referred to as employment in the tourism industry. All positions (or persons employed) delivering tourist- and non-tourism-characteristic services in all tourism-related establishments are referred to as employment in the tourism sector.

Assessing the employment demand linked with the tourism demand prediction is a strategic topic encompassing long-term human resource development considerations in both the private and public sectors (Stephen, Aiyan \& Stephan, 2004). Though tourism demand and forecasting research were very rare before 2000, it has attached much attention among academics as well as practitioners in the recent past (Hayian \& Gang, 2008). Most of these researches are heavily dependent on secondary data, and among them, tourist arrivals are a very important variable in tourism labour forecasting researches (Wanhill, 1992). According to Witt, Song \& Louvieris (2003), the vector autoregressive model is the most accurate forecasting method for long-term forecasting horizons (two and three years ahead). When we examine academic literature, it is clear that there has been an attempt to combine future tourism demand forecast with tourism impact analysis to examine the workforce requirement associated with tourism demand forecast (Stephen, Aiyan \& Stephan, 2004).

\section{RESEARCH METHODOLOGY}

To explore the forecasted values of labour in the hotel and restaurant sector for a future period, secondary data were used and analyzed using quantitative techniques. Annual data on tourist arrivals and different employment categories in the hotel and restaurant sector for the period of 2000 to 2018 were obtained from annual statistical reports from 2000 to 2018 published by Sri Lanka Tourism Development Authority (SLTDA). Tourist labour in Sri Lanka can be classified as direct labour and indirect labour. Out of direct labour, approximately $80 \%$ of labour is represented as hotel and restaurant labour and they are further divided as, managerial scientific and professional employment category, technical, clerical allied supervisory employment category, and manual and operative employment category. Tourist arrivals were considered dependent variable and employee categories (direct employment, employment in hotel and restaurant sector, managerial scientific and professional employment category, technical, clerical allied supervisory employment category, and manual and operative employment category) were considered as variables of this research. Karl Pearson's correlation was used to test the correlation between the factors such as direct employment, employment in hotel and restaurant sector, managerial scientific and professional employment category, technical, clerical allied supervisory employment category, and manual and operative employment category with tourist arrivals. Time series plots were used for pattern identification. Linear Regression Model was used for forecasting different employee categories for the future. Coefficient of determination was used to examine how differences in 
tourism arrival can be explained by different labour categories of the hotel and restaurant sectors.

\section{RESULT \& DISCUSSION}

In this research, the researcher make effort to identify the various relations between the dependent variable (tourist arrivals) with different independent variables such as direct employment, labour in the hotel and restaurant sector, managerial scientific \& professionals labour, technical clerical allied, supervisory and manual $\&$ operative labour. Karl Pearson's correlation was used to test the association between the factors and results exhibited in table 2 . There is a positive and very strong correlation between tourist arrivals and labour categories such as direct employment, hotel and restaurant labour, managerial scientific and professional employment category, technical, clerical allied supervisory employment category, and manual and operative employment category. They indicate that the growth of the above said employees' categories are highly determined by the number of tourist arrivals. The coefficient determination is above $80 \%$ and indicates more than 95 variations of their employee categories. Based on the above, it is evident that these labour categories depend on the country's effort to attract more tourists to the country. In addition to the above, there is a special labour category of tourism called tour guides. According to this analysis, there is a strong relationship between tour guides and tourist arrivals (coefficient of correlation $=0.83$ ) but the coefficient of determination is at 0.68 . It indicates that only $68 \%$ of tour guide variation only determined by tourist arrivals, but other factors impact $32 \%$ variation of tour guide employment.

\section{Table 1: Correlation Analysis Results}

\begin{tabular}{|c|c|c|c|c|c|}
\hline \multirow{2}{*}{ S/No. } & \multicolumn{2}{|c|}{ Correction Co-efficient } & \multicolumn{2}{c|}{ Co-efficient of determination } \\
\cline { 3 - 6 } & & $\begin{array}{c}\text { Co-relation } \\
\text { Co-efficient }\end{array}$ & $\begin{array}{c}\text { Round up } \\
\text { value of co- } \\
\text { relation co- } \\
\text { efficient }\end{array}$ & $\begin{array}{c}\text { Co-efficient } \\
\text { of } \\
\text { determination } \\
\text { value of co- } \\
\text { efficient } \\
\text { determination } \\
\text { (\%) }\end{array}$ \\
\hline 1 & $\begin{array}{c}\text { Tourist arrivals and } \\
\text { direct employment }\end{array}$ & 0.9785 & 0.98 & 0.957 & 96 \\
\hline 2 & $\begin{array}{c}\text { Tourist arrivals and } \\
\text { Hotel \& Restaurant }\end{array}$ & 0.9848 & 0.99 & 0.9699 & 97 \\
\hline 3 & $\begin{array}{c}\text { Tourist arrivals and } \\
\text { Guides }\end{array}$ & 0.8245 & 0.83 & 0.6798 & 68 \\
\hline 4 & $\begin{array}{c}\text { Tourist arrivals and } \\
\text { Managerial } \\
\text { Scientific \& } \\
\text { Professionals }\end{array}$ & 0.9831 & 0.99 & 0.9664 & 97 \\
\hline 5 & $\begin{array}{c}\text { Tourist arrivals and } \\
\text { Technical Clerical } \\
\text { Allied and } \\
\text { supervisory }\end{array}$ & 0.9787 & 0.98 & 0.9578 & 96 \\
\hline & $\begin{array}{c}\text { Tourist arrivals and } \\
\text { Manual \& } \\
\text { Operative }\end{array}$ & 0.987 & 0.99 & 0.9741 & 97 \\
\hline
\end{tabular}

During the projection period (2020 to 2024), tourism arrivals grow at an average annual rate of 4.8 per cent. Hotel and restaurant sector employees will be increased by 24898 during this period (2020 to 2024) and the annual average growth rate is at 4.7 per cent. It indicates that approximately both rates are the same and function together well. Since job market of the hotel and restaurant sector continually expanding over the 5 years periods simultaneously with tourism arrivals. Government, as well as private sector organizations, need to identify education and training opportunities in this sector. When it comes to Human Resource Management and policies in the hotel sector, training and development are some of the most important tools (Nickson \& Warhust, 2007). Based on the above data, educational organizations can decide their investments in this sector for a future time. Managerial employees in the hotel and restaurant sector will be increased by 3412 over the five-year consecutive period. The annual average growth rate of managerial employees in the hotel and restaurant sector is at 4.7 per cent. This indicates that how many white colour jobs should be created for the hotel and restaurant sector in the future. This information is vital for higher educational institutes such as universities to plan their future educational programs. The average annual growth rate is at 4.5 per cent. During this projection period (from 2020 to 2024) manual and operative employees are increased by 10406. The annual average growth rate of manual and operative employees is at 5 per cent. It indicates that manual and operative employees are increasing greater than other managerial employees. Even its growth rate is greater than the annual growth rate of tourist arrivals. Therefore, training institutes provide more educational programs in this sector and policymakers should facilitate introducing new educational solutions for these sectors. The Government should encourage both private and public educational organizations to design and implement appropriate short- and medium-term courses for this significant segment of the labour force and should provide more opportunities in learning in this sector. Tour guiding is another important profession in the tourism industry. They are direct contact part of any visitors. According to this analysis, the number of tour guides should be increased by 674 persons during this period (from 2020 to 2024). since the training of tour guides is solely responsible by Sri Lanka Tourism and Hotel Management (SLITHM), this should be a good input for their future educational planning. Ultimately all these forecasted values of the labour market become very important input for all policymakers, practitioners who are related to the tourism sector. 
Table 2: Forecasting Analysis of Labor Categories of Hotel Restaurant Sector

\begin{tabular}{|c|c|c|c|c|}
\hline Year & Forecast (Tourist Arrivals) & Forecast & Lower Confidence Bound & Upper Confidence Bound \\
\hline \multicolumn{5}{|c|}{ Hotel and Restaurant } \\
\hline 2020 & $2,019,025$ & 121,207 & 102,177 & 140,237 \\
\hline 2021 & $2,124,347$ & 127,432 & 100,533 & 154,330 \\
\hline 2022 & $2,229,670$ & 133,656 & 100,707 & 166,605 \\
\hline 2023 & $2,334,992$ & 139,881 & 101,822 & 177,940 \\
\hline 2024 & $2,440,315$ & 146,105 & 103,537 & 188,674 \\
\hline \multicolumn{5}{|c|}{ Managerial Scientific \& Professional } \\
\hline 2020 & $2,019,025$ & 16,572 & 13,964 & 19,180 \\
\hline 2021 & $2,124,347$ & 17,425 & 13,738 & 21,111 \\
\hline 2022 & $2,229,670$ & 18,278 & 13,762 & 22,794 \\
\hline 2023 & $2,334,992$ & 19,131 & 13,915 & 24,347 \\
\hline 2024 & $2,440,315$ & 19,984 & 14,150 & 25,818 \\
\hline \multicolumn{5}{|c|}{ Technical Clerical Allied and supervisory } \\
\hline 2020 & $2,019,025$ & 57,181 & 48,713 & 65,650 \\
\hline 2021 & $2,124,347$ & 59,951 & 47,981 & 71,921 \\
\hline 2022 & $2,229,670$ & 62,721 & 48,059 & 77,384 \\
\hline 2023 & $2,334,992$ & 65,491 & 48,555 & 82,428 \\
\hline 2024 & $2,440,315$ & 68,261 & 49,318 & 87,205 \\
\hline \multicolumn{5}{|c|}{ Manual and Operative } \\
\hline 2020 & $2,019,025$ & 47,455 & 39,502 & 55,408 \\
\hline 2021 & $2,124,347$ & 50,057 & 38,815 & 61,299 \\
\hline 2022 & $2,229,670$ & 52,658 & 38,888 & 66,429 \\
\hline 2023 & $2,334,992$ & 55,260 & 39,353 & 71,166 \\
\hline 2024 & $2,440,315$ & 57,861 & 40,070 & 75,652 \\
\hline \multicolumn{5}{|c|}{ Guides } \\
\hline 2020 & $2,019,025$ & 4,978 & 4,463 & 5,493 \\
\hline 2021 & $2,124,347$ & 5,146 & 4,418 & 5,875 \\
\hline 2022 & $2,229,670$ & 5,315 & 4,423 & 6,207 \\
\hline 2023 & $2,334,992$ & 5,483 & 4,453 & 6,514 \\
\hline 2024 & $2,440,315$ & 5,652 & 4,499 & 6,804 \\
\hline
\end{tabular}

Though the latest developed forecasting techniques gave improved forecast accuracy, some researchers (Haiyan \& Gang, 2008) are raising voice that there should be both quantitative and qualitative research methods to be used to increase the accuracy of forecasting of future trends of the tourism industry. According to Witt, Song \&
Louvieris (2003), there has been a dearth of tourism demand estimates that include tourism impact analysis to assess workforce requirements linked with tourism demand forecasts. This research can fill the above empirical gap of tourism labour. The countries like Denmark used this model to increase the accuracy of 
forecasts (Stephen, Aiyan \& Stephan, 2004). The forecasted annual average growth rate of employment in the hotel and restaurant sector is identical to the annual growth of tourist arrival in-country. But a country like Australia, there is a significant difference between these two variables. A country like Canada has to face the problem of labour shortage to continue operation. The reason is their tourism industries are mostly developing as capital and technology-intensive industries. But the tourism industry in Sri Lanka remains a highly laborintensive industry.

\section{CONCLUSION}

The aim of this study is to forecast the labour requirement of the hotel and restaurant sector and more specifically the different labour categories of the hotel and restaurant sector in Sri Lanka. The growing importance of the tourism industry, as well as the relative labour intensity of accommodation as a crucial aspect of a country's tourism offering, make this an important subject to explore. Tourism arrivals are annually increased by 4.8 per cent and employees of hotel and restaurant sector also increase by 4.7 per cent simultaneously. This projection shows that we still operate our industry as a labor-intensive industry. Therefore, a skillful, well-trained labour force may be the greatest asset for the development of the industry in the future. Developing and maintaining well-trained and skilled labour is the challenge faced by many firms in the industry. Hence policymakers need to make decisions to provide more institutional facilities to develop these labour categories in this sector.

Looking forward, this research merits future research engagement as the needs of the hotel and restaurant sector and its diverse workforce evolves in an everchanging environment. Evaluating the extent to which the future accurately enhances the efficacy of successive future research. This type of research can avoid the risk and uncertainties involved with future planning. There are certain drawbacks to this study, which was based exclusively on secondary data acquired from a single source over a short period of time. The future study might be extended with a focus on forecasted results of the hotel and restaurant sector. In fact, this is the ideal time for Sri Lanka to develop a solid plan to strengthen its human resources in both quantity and quality. The value of human resources in the hotel and restaurant industry in Sri Lanka was analysed in this study for the future.

\section{Conflict of Interests}

The authors declare that they have no conflict of interests.

\section{ACKNOWLEDGEMENT}

The authors are thankful to the institutional authority for completion of the work.

\section{REFERENCES}

Armstrong, M., \& Taylor, S. (2020). Armstrong's handbook of human resource management practice.

Asian Development Bank (ADB) International Labour Organisation. Regional Office for Labour and the Pacific. (2017). Sri Lanka: fostering workforce skills through education: employment diagnostic study.

Central Bank of Sri Lanka. (2019). Central Bank of Sri Lanka Annual Report. Central Bank of Sri Lanka.

Dickens, W., \& Lang, K. (1991). An Analysis of the Nature of Unemployment in Sri Lanka. Journal of Development Studies, 31(4), 129-158.

Dritsakis, N. (2004). Tourism as a Long-Run Economic Growth Factor: An Empirical Investigation for Greece using Causality Analysis. Tourism Economics, 10(3), 305-316.

Haiyan, S., \& Gang, L. (2008). Tourism Demand Modelling and Forecasting, Tourism Management, 29(2), 203-220.

ILO. (2020). Platformization of the Tourism Sector in Sri Lanka: Impacts on Labour Market and Decent Work Opportunities. Tandem Research. https:// www.ilo.org/wcmsp5/groups/public/---asia/---robangkok/documents/publication/wcms_755007.pdf

Massidda, C., \& Mattana, P. (2013). A SVECM Analysis of the Relationship between International Tourism Arrivals, GDP and Trade in Italy. Journal of Travel research, 52(1), 93 -105.

Mihalic, T. (2016). Sustainable-Responsible Tourism Discourse - Towards 'Reasonable Tourism. Journal of Cleaner Production, 111, 461-470.

Neugart, M., \& Schömann, K. (2002). Employment Outlooks: Why forecast the labour market and for whom?

O'Connell, P. J., \& MacGinnity, F. (1996). What works, who works? The impact of active labour market programmes on the employment prospects of young people in Ireland (No. FS I 96-207). WZB Discussion Paper.

Oneţiu, A. N., \& Predonu, A. M. (2013). Effects of tourism on labour market. Procedia-Social and 
Behavioral Sciences, 92, 652-655.

Ritchie J. R. B., \& Goeldner, C. R. (1987). Travel, Tourism and Hospitality Research: A Handbook for Managers and Researchers, Journal of Travel Research, 25(4), 40-60.

SLTDA. (2019). Tourism Research and Statistics. Sri Lanka Tourism Development Authority. https:// sltda.gov.lk/en/statistics

Sri Lanka Labour Force Survey. (2019). Annual Report - 2019. Department of Census and Statistics. http://www.statistics.gov. 1k/Labour Force/StaticalInformation/AnnualReports

Stephen, F., Aiyan, S., \& Stephen, W. (2004). Forecasting Tourism Generated Employment The Case of Denmark. Tourism Economic, 10(2), 167-176.

Suresh, J., \& Senthilnathan, S. (2014). Relationship between tourism and economic growth in Sri Lanka. Published as the $7^{\text {th }}$ chapter of a book entitled "Economic Issues in Sri Lanka" compiled by Dr. S. Vijayakumar, 115-132.

Umasuthan, H., \& Park, O. (2018). The Challengers Faced by Hotel Service Industry in Sri Lanka. International Journal of Tourism Science, 5(2), 77-88.

Wanhill, S. (1992). Tourism manpower planning: the case of Nepal. Tourism manpower planning: the case of Nepal, 87-104.

Warhurst, C., \& Nickson, D. (2007). Employee experience of aesthetic labour in retail and hospitality. Work, employment and society, 21(1), 103-120.

Witt, S.F., Song, H., \& Louvieris, P. (2003). Statistical Testing in Forecasting Model Selection. Journal of Travel Research,42(2), 151-158. 